\title{
Reorganization of the Y Chromosomes Enhances Divergence in Israeli Mole Rats Nannospalax ehrenbergi (Spalacidae, Rodentia): Comparative Analysis of Meiotic and Mitotic Chromosomes
}

\author{
Sergey Matveevsky ${ }^{1, *(\mathbb{D})}$, Elena Ivanitskaya ${ }^{2}$, Victor Spangenberg ${ }^{1}{ }^{(\mathbb{D})}$, \\ Irina Bakloushinskaya ${ }^{3}$ (D) and Oxana Kolomiets ${ }^{1}$ \\ 1 Vavilov Institute of General Genetics, Russian Academy of Sciences, Moscow 119991, Russia; \\ v.spangenberg@gmail.com (V.S.); olkolomiets@mail.ru (O.K.) \\ 2 Institute of Evolution, Haifa University, Haifa 31905, Israel; lenaiva@research.haifa.ac.il \\ 3 Koltzov Institute of Developmental Biology, Russian Academy of Sciences, Moscow 119334, Russia; \\ irina.bakl@gmail.com \\ * Correspondence: sergey8585@mail.ru; Tel.: +7-499-135-5361
}

Received: 29 March 2018; Accepted: 22 May 2018; Published: 24 May 2018

\begin{abstract}
The Y chromosome in mammals is variable, even in closely related species. Middle East blind mole rats Nannospalax ehrenbergi demonstrate autosomal variability, which probably leads to speciation. Here, we compare the mitotic and meiotic chromosomes of mole rats. For the first time, we studied the behavior of their sex chromosomes in the meiotic prophase I using electron microscopy and immunocytochemical analysis. Unexpectedly, the sex chromosomes of the 52- and 60-chromosome forms of mole rats showed different synaptic and recombination patterns due to distinct locations of the centromeres on the $\mathrm{Y}$ chromosomes. The absence of recombination in the 60-chromosome form, the asymmetric synapsis, and the short-term disturbance in the synaptic co-orientation of the telomeric regions of the $\mathrm{X}$ and $\mathrm{Y}$ chromosomes were revealed as specific features of mole rat sex bivalents. We suggest several scenarios of $Y$ chromosome alteration in connection with species differentiation in mole rats.
\end{abstract}

Keywords: Nannospalax ehrenbergi; chromosome forms; meiosis; synaptonemal complex; Y chromosome; sex bivalent; asymmetric synapsis; recombination; chromosome evolution

\section{Introduction}

Sex chromosomes are highly specialized elements of the genome that differ from autosomes in terms of specific gene contents, distinct behavior in meiosis, and a variety of evolutionary paths [1]. Sex chromosomes demonstrate an amazing diversity in animals [2], particularly in mammals [3-5]. In placental mammals, sex chromosomes evolved over 180 million years and appear to be heteromorphic, $\mathrm{X}$ and $\mathrm{Y}$ chromosomes, except in some cases of multiple sex chromosomes (several Xs or several Ys, or both) or, extraordinarily, lack of a Y [3,6-8]. In comparison with the $\mathrm{X}$ chromosome, which is large and rich in genes, the $\mathrm{Y}$ chromosome in most mammals is small, heterochromatic, and contains significantly fewer genes $[9,10]$. The $\mathrm{Y}$ chromosome is often subjected to various structural changes and additions.

A genetic linkage for male-specific genes was selected as soon as male-determining genes emerged on a proto-Y chromosome [11-15]. The dark side of the specialization appeared to be a deficiency in recombination due to the absence of homological regions between $X$ and $Y$ chromosomes, the declining force of natural selection, accumulating deleterious mutations, and further degradation 
of the $\mathrm{Y}$ chromosome [16-18]. The $\mathrm{Y}$ chromosome may disappear, as in four species of mole voles Ellobius [4,19-21] and some species of spiny mice Tokudaia [22]. Several possible ways of slowing down the decay of the $Y$ chromosome were hypothesized, for example by gene duplications, adding repeats, doubling and translocating parts of $X$, or fusing with autosomes or their parts [23-26]. If an autosome or some part of it is translocated onto Y, so called 'neo' sex chromosomes form, as in spiny mice Tokudaia muenninki [27], Indian mongoose Herpestes auropunctatus [28,29], and South-American primates Aotus $[30,31]$ and Alouatta $[32,33]$. A comparison of $\mathrm{Y}$ in different primate species made it possible to conclude that there are pericentric inversions in the early stages of the primates' evolution [34]. In most mammals, the pseudoautosomal region (PAR) is a short region of homology, allowing pairing and recombination that is required for faithful segregation of the male sex chromosomes [35]. The non-combining part of the human $Y$ chromosome underwent four overlapping inversions, which resulted in a reduction in the PAR length [36]. Inverse polymorphism of the Y chromosome in different human populations [37,38], pericentric inversion in $Y$ in infertile men [39], and neodicentricity of the human Y [40] have been identified.

Middle East, or Palestine, blind mole rats Nannospalax ehrenbergi (Nehring, 1898) are especially interesting, because they demonstrate high autosome variability [41,42]. These animals are of particular interest to geneticists, physiologists, and medical researchers. They are distinguished by a unique anti-carcinogenic system, unusual longevity for rodents, adaptation to conditions of hypoxia, and vision reduction [43-46].

Populations of N. ehrenbergi occupy open areas in southeastern Anatolia, northern Iraq, Syria, Lebanon, Jordan, and Israel, with local coastal populations in Northern Egypt and Libya (Figure 1a). To date, 19 chromosomal forms have been identified in blind mole rats (for a review, see [47]), four of which inhabit Israel: $2 n=52,2 n=54,2 n=58$, and $2 n=60$ [42,48,49] (Figure 1b). In N. ehrenbergi, the $X$ chromosome is a mid-length submetacentric with a small block of pericentromeric heterochromatin. The $\mathrm{Y}$ chromosome is a small acrocentric, carrying a large pericentromeric block of heterochromatin [48]. Such characteristics of the sex chromosomes are similar to those in other species of the genus Nannospalax, although there are some differences between them [50,51]. Mole rats are a fruitful model for studying the co-evolution of sex chromosomes and highly variable autosomes and for estimating the evolutionary consequences of chromosome alterations.
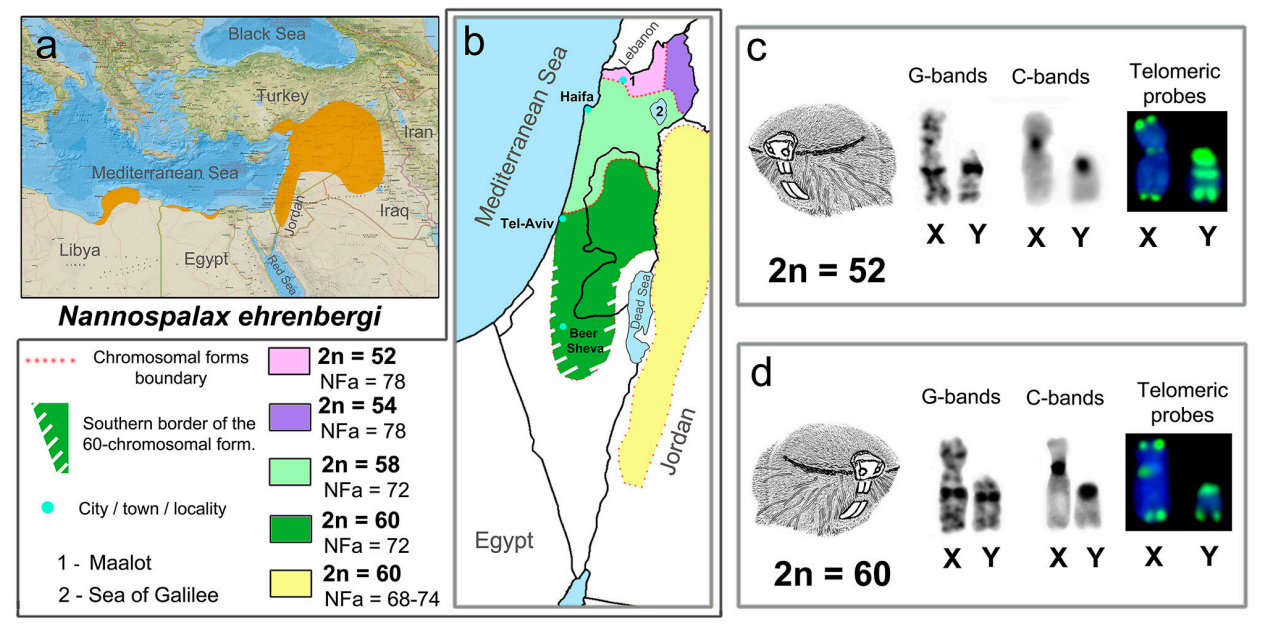

Figure 1. Geographical distribution and sex chromosomes of two chromosomal forms of Nannospalax ehrenbergi in Israel. (a) The geographic range of the N. ehrenbergi superspecies (from the IUCN Red List of Threatened Species; http:/ / www.iucnredlist.org); (b) distribution of chromosomal forms of mole rats in Israel and Jordan on the basis of Nevo et al. [48], Qumsiyeh [49], and [51]; (c,d) sex chromosomes of mole rat forms with $2 \mathrm{n}=52, \mathrm{NFa}=78$ (c) and $2 \mathrm{n}=60, \mathrm{NFa}=72$ (d). Fluorescent in situ hybridization (FISH): telomeric probes (green), DAPI (blue). NFa-number of the autosomal arms. 
The structure and behavior of the sex chromosomes in meiosis in blind mole rats appears to be almost unknown. Some details of sex chromosome synapsis in a 55-chromosome hybrid male N. ehrenbergi were described by Wahrman et al. [42]. There are no other data on the features of synapsis and recombination of the sex chromosomes in blind mole rats. The aim of our work was to conduct a detailed electron-microscopic and immunocytochemical analysis of synapsis and recombination of the sex chromosomes in two forms of N. ehrenbergi from Israel and to clarify if alterations in the sex chromosomes could facilitate a divergence of the forms.

\section{Materials and Methods}

\subsection{Animals}

Electron-microscopic and immunocytochemical analyses were carried out in two male blind mole rats, which were caught in the geographic range of the chromosomal form with $2 n=60, N F=72$ (vicinity of Beer Sheva: $31^{\circ} 14^{\prime} 30.8^{\prime \prime} \mathrm{N} \times 34^{\circ} 42^{\prime} 11^{\prime \prime} \mathrm{E}$ ), and two males with $2 \mathrm{n}=52, \mathrm{NFa}=78$ which were caught near Miilya village, Upper Galilee $\left(33^{\circ} 01^{\prime} 32.6^{\prime \prime} \mathrm{N}, 35^{\circ} 14^{\prime} 51.8^{\prime \prime} \mathrm{E}\right)$.

Analysis of the G- and C-banding patterns and of the distribution of telomeric sequences in mitotic chromosomes were also performed for two males of $2 n=60$ from Lahav (vicinity of Beer Sheva: $\left.31^{\circ} 22^{\prime} 41.87^{\prime \prime} \mathrm{N}, 34^{\circ} 52^{\prime} 13.43^{\prime \prime} \mathrm{E}\right)$, two males of $2 \mathrm{n}=58$ from Muchraka, Mount Carmel $\left(32^{\circ} 44^{\prime} 34.7^{\prime \prime} \mathrm{N}\right.$, $\left.35^{\circ} 02^{\prime} 54.2^{\prime \prime} \mathrm{E}\right)$, one male of $2 \mathrm{n}=54$ from Al Qunaitra $\left(33^{\circ} 07^{\prime} 15.5^{\prime \prime} \mathrm{N}, 35^{\circ} 51^{\prime} 04.2^{\prime \prime} \mathrm{E}\right)$, and two males of $2 \mathrm{n}=52$ from Kerem Ben Zimra $\left(33^{\circ} 01^{\prime} 56.9^{\prime \prime} \mathrm{N}, 35^{\circ} 28^{\prime} 16.5^{\prime \prime} \mathrm{E}\right)$.

The manipulations of the animals were carried out in accordance with the international rules of the Manual on Humane Use of Animals in Biomedical Research [52] and the rules of the Ethics Committee for Animal Research of the Vavilov Institute of General Genetics (protocol No. 3 from 10 November 2016).

\subsection{Preparation of Mitotic Chromosomes and Fluorescent In-Situ Hybridization}

Mitotic metaphases were obtained from bone marrow cells [53]. Chromosome slides were prepared according to the standard air-drying technique. The C-banding technique was performed as described by Sumner [54]. To obtain G-banded chromosomes, we used a simple two-step method (modified method from Seabright [55]). For the localization of telomeric sequences, we used commercially available telomeric (TTAGGG)n probes labeled with biotin-16-dUTP (Roche Biomolecular, Indianapolis, IN, USA), detected with avidin-FITC (Vector Laboratories, Burlingame, CA, USA). The hybridization was carried out at $37^{\circ} \mathrm{C}$ overnight. The chromosomes were counterstained with DAPI.

\subsection{Preparation of Meiotic Chromosomes}

The spreading of meiotic chromosomes was performed according to Navarro et al. [56]. The spermatocytes were spread on a hypotonic solution of sucrose $(0.2 \mathrm{M})$ and fixed in $4 \%$ paraformaldehyde ( $\mathrm{pH}$ 8.2), then washed in $0.4 \%$ Photo-Flo solution (Kodak, Rochester, NY, USA), dried, and kept at $-20^{\circ} \mathrm{C}$. The spreads were prepared on slides coated with a Falcon film, contrasted with a 50\% solution of silver nitrate, and examined under the electron microscope Jem-1011 (Jeol, Tokyo, Japan). For immunocytological analyses, the spreads were prepared on slides with poly-L-lysine.

\subsection{Antibodies and Immunostaining}

All antibodies were diluted in phosphate-buffered saline (PBS) containing $3 \%$ bovine serum albumin (BSA) and $0.05 \%$ Triton-X-100. We used the following primary antibodies (Abcam, Cambridge, UK): for the immunodetection of axial/lateral elements, rabbit anti-SYCP3 antibody at a 1:500 dilution; for the identification of the central element, rabbit anti-SYCP1 antibody at a 1:500 dilution; for the detection of late recombination nodules, mouse anti-MLH1 antibody at a 1:50 dilution. To identify the kinetochore proteins, we used human CREST antibody at a 1:600 dilution (Fitzgerald Industries International Inc., Concord, MA, USA). 
We used the following secondary antibodies: goat anti-rabbit IgG, Alexa Fluor 488-conjugate (Invitrogen, Carlsbad, CA, USA); goat anti-human IgG, Alexa Fluor 555-conjugate (Invitrogen); goat anti-mouse IgG, fluorescein isothiocyanate (FITC)-conjugate (Jackson Immunoresearch Laboratories, West Grove, PA, USA). The procedure of immunostaining has been described in detail elsewhere [20,57]. The analysis of the slides with spreads was carried out using the fluorescence light microscope Axio Imager D1 (Carl Zeiss, Jena, Germany). A total of 322 spread meiotic nuclei of 60-chromosome mole rats and 108 spread meiotic nuclei of 52-chromosome mole rats were examined.

\section{Results}

\subsection{Mitotic and Meiotic Chromosomes of 52- and 60-Chromosome Mole Rats}

The size, morphology, and G- and C-banding patterns of the sex chromosomes of the mitotic spreads were similar in all Israeli chromosomal forms. Fluorescence in situ hybridization (FISH) of (TTAGGG) $)_{7}$ probes revealed telomeric signals of varying intensity at all sex chromosome termini for all chromosomal forms. The $\mathrm{X}$ chromosomes showed a weak unstable telomeric signal in the centromeric region. The distribution and intensity of the hybridization signal in the $Y$ chromosome of the $2 n=60$ and $2 n=58$ forms did not differ from the pattern of telomeric sequences in acrocentric autosomes. The $Y$ chromosomes in the $2 n=54$ and $2 n=52$ forms presented enlarged blocks of a near-centromeric signal, more prominent than the distal signal in autosomes, and a bright interstitial band of telomeric sequences (Figure 1c,d) [58,59].

As predicted, in the spermatocytes of mole rats with 52 chromosomes, 25 autosomal bivalents formed, and thus we were able to distinguish the 25 complete synaptonemal complexes (SCs) and the sex bivalent at the pachytene stage (Figure 2a). The sex chromosomes were moved to the periphery of the meiotic nucleus and formed the so-called sex body (Figure 2a). SCs numbered 1-7 corresponded to large meta- and submetacentric chromosomes, the 8-15 to large and medium acrocentrics, the 16-19 to medium submetacentrics, the 21-24 to small submetacentrics, and the 20 and 25 to acrocentrics. The numbers were identical to the 52-chromosome karyotype [58].
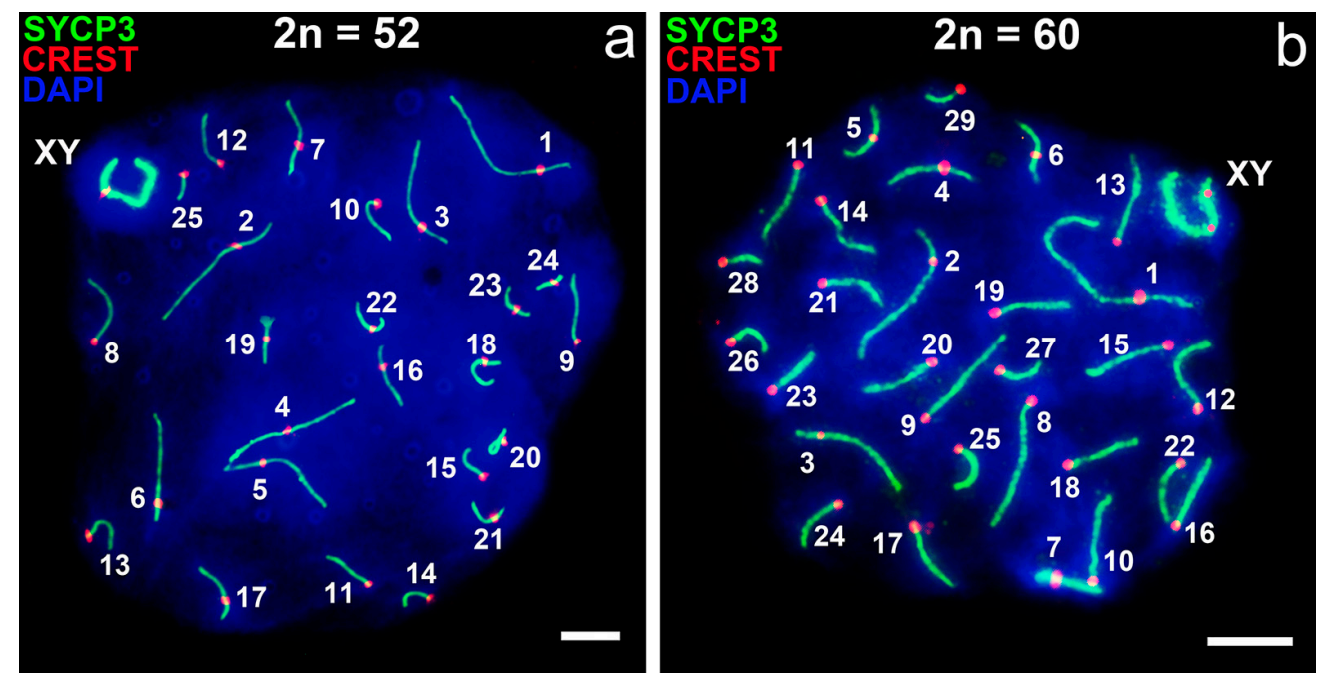

Figure 2. Pachytene spermatocytes of two chromosomal forms of N. ehrenbergi. Immunostaining with antibodies to SYCP3 (green) and the centromere (CREST, red). DAPI-stained chromatin (blue). (a) Form $2 n=52 ; 25$ synaptonemal complexes (SCs) and XY bivalent are formed; (b) form $2 n=60 ; 29$ SCs and $\mathrm{XY}$ bivalent are formed. Scale bar $(\mathbf{a}, \mathbf{b})=5 \mu \mathrm{m}$.

At the pachytene stage, 29 complete SCs and sex bivalents were formed in the spermatocytes of mole rats with 60 chromosomes (Figure $2 \mathrm{~b}$ ). The sex chromosomes were moved to the periphery of the meiotic nucleus and formed the sex body (Figure 2b). SC bivalents denoted 1-7 corresponded to large 
and medium bi-armed chromosomes and those denoted 8-29 to large, medium, and small acrocentrics. The numbers correspond to the karyotype of $2 n=60$ [58].

\subsection{Synapsis of the Mole Rat Sex Chromosomes}

The analysis of synapsis on the sex chromosomes, following SYCP3 (synaptonemal complex protein 3) and CREST (Calcinosis Raynaud's phenomenon, Esophageal dysmotility, Sclerodactyly, and Telangiectasia) immunostaining, revealed unexpected results. We found that sex chromosomes of different chromosomal forms, which have almost identical patterns of G- and C-bands, formed sex bivalents of dissimilar configuration. In 60-chromosome mole rats, the synapsis began from the pericentromeric region of the acrocentrical $Y$, while, in 52-chromosome mole rats, it started at the distal area of the acrocentric $Y$ (Figure $3 b-d, g-i)$. The centromere positions in the $Y$ chromosomes marked these apparently different synapsis (Figures 2 and $3 a, f$ ). In the mole rats with $2 n=60$, the centromere of the $\mathrm{Y}$ in sex bivalents was located at the peritelomeric end of the SC. In the form with $2 \mathrm{n}=52$, the centromere of the $Y$ laid near the centromere of the submetacentric $X$ chromosome (Figure $3 d, i)$. The SYCP1 antibodies detected the central element of the SC in both forms of mole rats (Figure 3c,h).
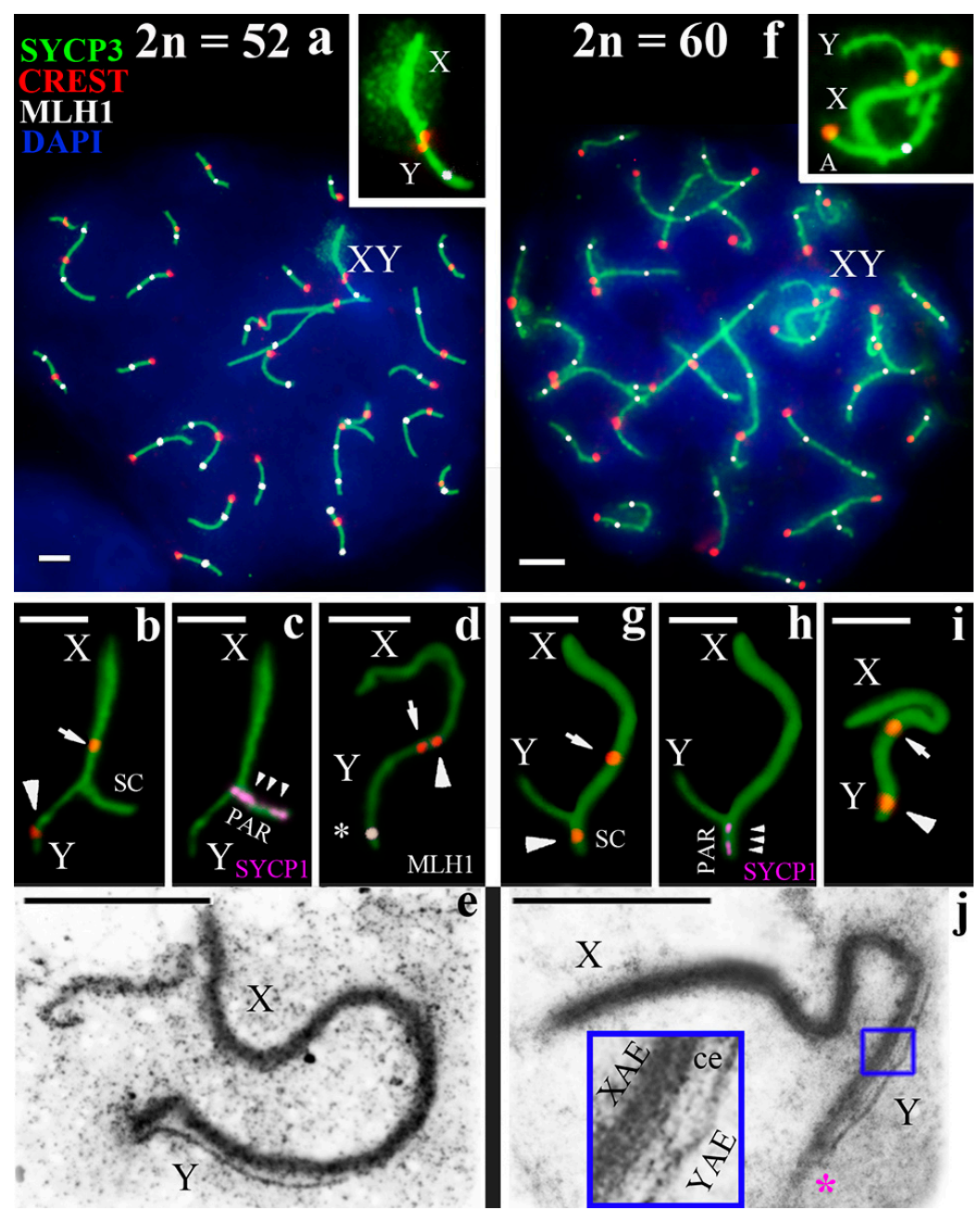

Figure 3. Spermatocytes and sex $(X, Y)$ chromosomes of two chromosomal forms of mole rats $N$. ehrenbergi. (a-e) Form with $2 \mathrm{n}=52 ;(\mathbf{f}-\mathbf{j})$ form with $2 \mathrm{n}=60$. $(\mathbf{a}, \mathbf{f})$ Pachytene spermatocytes of the forms with $2 n=52$ (a) and $2 n=60$ (f). The sex chromosomes are enlarged in the insets. A-autosome; $(\mathbf{b}-\mathbf{e}, \mathbf{g}-\mathbf{j}) \operatorname{sex}(\mathrm{XY})$ bivalent at the late zygotene to early pachytene $(\mathbf{b}, \mathbf{c}, \mathbf{g}, \mathbf{h})$, and mid pachytene $(\mathbf{d}, \mathbf{i})$ stages; (a-d,f-i) The axial SC elements were identified using anti-SYCP3 antibodies (green), the central element with anti-SCP1 antibodies (magenta), the recombination nodules with anti-MLH1 antibodies 
(white), and anti-CREST antibodies were used for the kinetochores (red). DAPI-stained chromatin (blue). SC: synaptonemal comlex or synaptic cite $(\mathbf{b}, \mathbf{g})$; at sex bivalents, the arrow indicates the centromere of the $\mathrm{X}$ chromosome, and the arrowhead indicates the centromere of the $\mathrm{Y}$ chromosome $(\mathbf{b}, \mathbf{d}, \mathbf{g}, \mathbf{i})$; the asterisk indicates the MLH1 focus (d). The central elements of the SC are formed in the synaptic regions of the sex chromosomes of both mole rats chromosomal forms (the localization of SYCP1 is indicated by three small arrowheads) (c,h); PAR-pseudoautosomal region; (e,j) Electron micrographs of a sex bivalent, $X Y$ at the mid pachytene stage. The pink asterisk marks synaptic differences in the telomeric sites of $X$ and $Y$. The blue square marks the site in the inset. XAE denotes axial elements of the $\mathrm{X}$ chromosome; YAE denotes axial elements of the $\mathrm{Y}$ chromosome; ce denotes the central element. Scale bar $(\mathbf{a}-\mathbf{j})=2 \mu \mathrm{m}$.

Using electron microscopy, we detected no significant differences in the synapsis of the sex chromosomes in the spermatocytes of the 52- and 60-chromosome forms. At the mid pachytene stage, the synapsis between the $X$ and $Y$ extended over the entire $Y$ chromosome in both forms. Additionally, asynaptic and synaptic segments of the $X$ were significantly thicker (3-5 times) than the $Y$ axis (Figure 3e,j, see inset). Previously, the asymmetry in the structure of synaptic segments of the sex chromosomes was termed asymmetric synapsis, and the SC was called asymmetric [60]. It should be noted that there were short-term synaptic differences in the telomere sites of $X$ and $Y$ exclusively in mole rats with $2 \mathrm{n}=60$ (Figure $3 \mathrm{j}$ ).

The synaptic dynamics of sex chromosomes in prophase I in the 60-chromosome mole rats deserve special attention. The axial elements of the sex chromosomes were not thickened and formed a short SC at the mid zygotene stage (Figure $4 \mathrm{a}, \mathrm{d}$ ). Perhaps, this synaptic site is a true PAR. Later, the unpaired segment of the $Y$ chromosome was co-aligned with the $X$ chromosome; a synaptic adjustment might be a possible interpretation. At the mid pachytene stage, the thin $Y$ axis lay along the thickened $X$ axis (Figure $4 \mathrm{~b}, \mathrm{e}$ ). At the late pachytene and early diplotene stages, the axial elements of the $\mathrm{X}$ and $Y$ chromosomes formed a tangle at the periphery of the meiotic nucleus (Figure 2); the tangle was surrounded by electron-dense material. Thus, the sex chromosomes formed the sex body in a way typical of mammals (Figure 4c,f). The SYCP3 signals were distributed throughout the entire sex body at these stages (Figure $4 \mathrm{f}$ ).

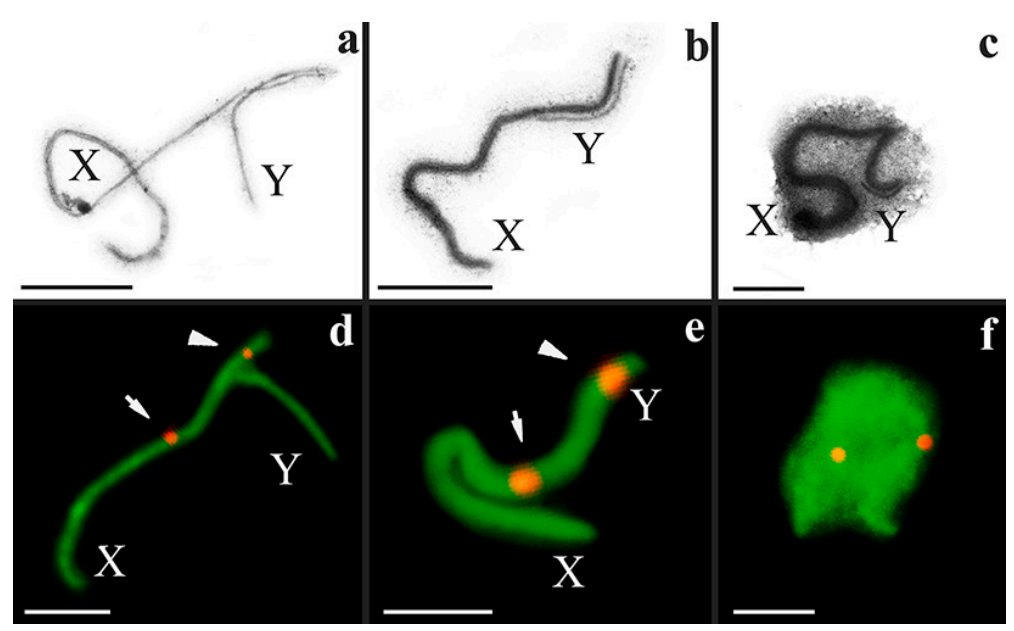

Figure 4. Sex chromosomes of $N$. ehrenbergi with $2 \mathrm{n}=60$ at different stages of meiotic prophase I. (a-c) Electron micrographs of a sex bivalent; (d-f) light microphotos of sex bivalents. Immunostaining with antibodies to SYCP3 (green) and to the centromere (CREST, red); (a,d) late zygotene to early pachytene stages; (b,e) mid pachytene stage; (c,f) late pachytene stage. At sex bivalents, the arrow indicates the centromere of the $\mathrm{X}$ chromosome; the arrowhead indicates the centromere of the $\mathrm{Y}$ chromosome. Scale $\operatorname{bar}(\mathbf{a}-\mathbf{f})=2 \mu \mathrm{m}$. 


\subsection{Recombination of the Mole Rat Sex Chromosomes}

A DNA mismatch repair protein MLH1 (mutL homolog 1) was localized in late-recombination nodules [61]. In the mole rats studied, MLH1 foci were identified in 53 spermatocytes of the 52-chromosome form and in 207 cells of the 60-chromosome form; one-two MLH1 foci were identified in each arm of autosomal bivalents, both in the terminal and in the interstitial regions at the pachytene stage. Only one small bivalent did not have an MLH1 signal (Figure 3a,f). This was typical for both forms of mole rats.

However, the MLH1 foci in the sex bivalents were exposed differently. One MLH1 focus was detected in the sex bivalents in nine of the 53 meiotic nuclei of the $2 n=52$ form (Figure $3 a$, $d$ and Figure 5a,d1). The average distance of the MLH1 signal position was $0.85 \pm 0.2 \mu \mathrm{m}$ (mean values \pm standard deviation (SD)) from the telomeric site of the synaptic segment of the sex bivalents in mole rats of the $2 n=52$ form (Figure $5 c$ ). In the $2 n=60$ form, MLH1 foci in the XY bivalent were not detected in any cells immunostained with anti-MLH1 antibodies (Figure 5b,d2), although MLH1 foci were identified in autosomes.

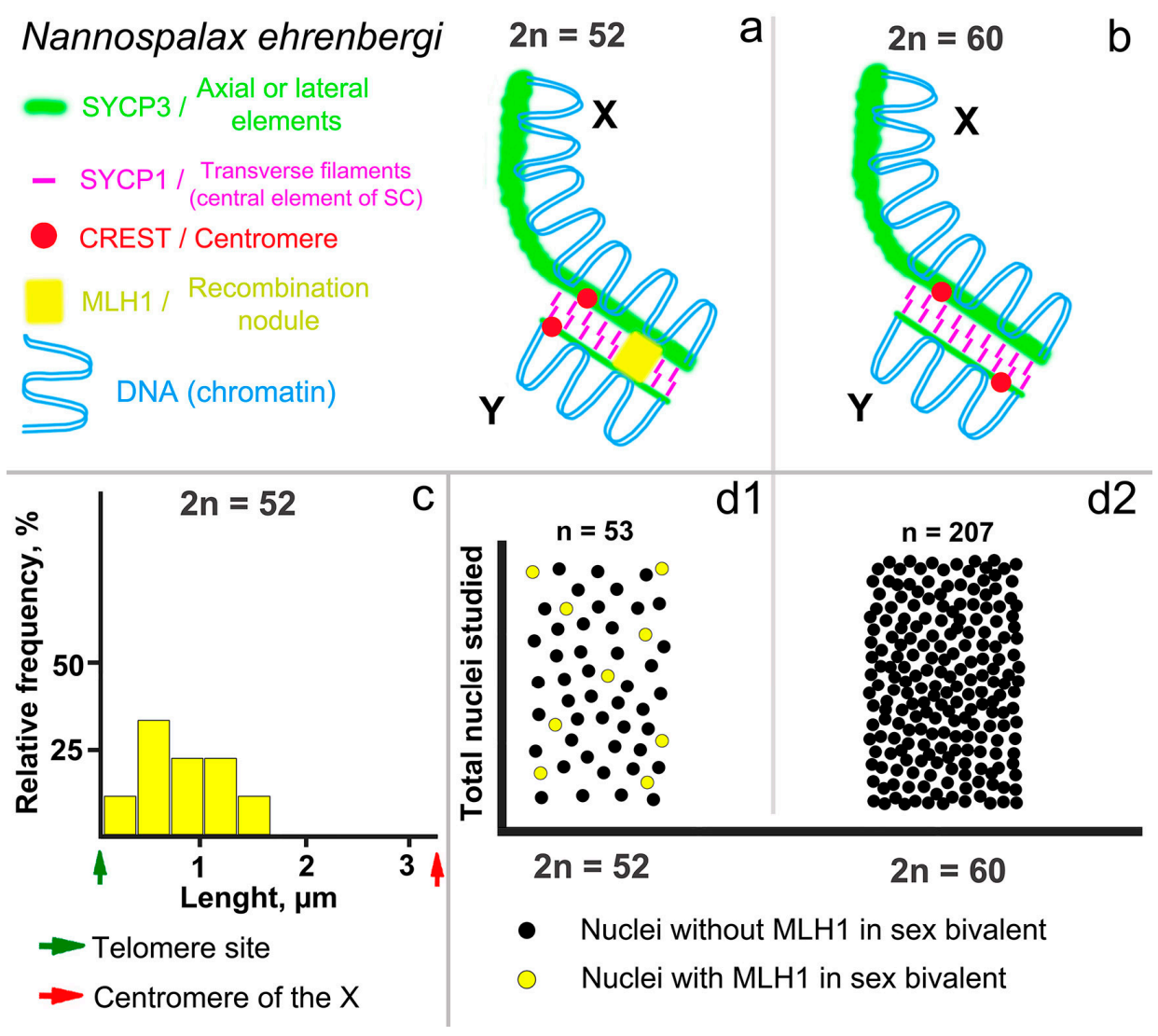

Figure 5. Scheme of synaptic and recombination patterns of mid pachytene XY of N. ehrenbergi. Sex bivalent of the 52-chromosome (a) and 60-chromosome (b) forms of mole rats. The centromeres of the acrocentric $\mathrm{Y}$ chromosome of the two forms have different localizations in the sex bivalent. The distribution of MLH1 foci in the synaptic site of the XY bivalent of the 52-chromosome mole rats is shown in the histogram (c). The $x$-axis presents the average length of the synaptic site of the sex bivalent in $\mu \mathrm{m}$; the $y$-axis shows the relative frequency of MLH 1 foci in each $10 \%$ of the length of the synaptic site of the sex bivalent. The frequency of MLH1 is presented graphically as yellow bars. The data were calculated and presented using GraphPad Prism Version 5.0 (GraphPad Software, San Diego, CA, USA). The total number of nuclei studied in the 52-(d1) and 60-(d2) chromosome forms of mole rats is represented graphically by black and yellow dots. MLH1 signals in the XY bivalents of the form with $2 \mathrm{n}=60$ were not detected. 


\section{Discussion}

\subsection{Specific Structure of the Nannospalax ehrenbergi XY Bivalent}

Interestingly, mole rat $X$ and $Y$ axes of different thicknesses are involved in synapsis. Such asymmetric synapsis is rare. In most mammals, the synaptic $X$ and $Y$ regions have the same or similar thicknesses [62-65]. Asymmetric patterns of sex chromosome synapsis have been observed in Norway rat and chinchilla $[60,66]$. It has been suggested that synapsis occurred between non-homologous chromosomes or non-homologous regions of the sex chromosomes. We believe that the presence of a recombination nodule and a central element in the asymmetric SC of the mole rat sex bivalent indicates at least a partial homology of these segments. Perhaps, these differences in the thicknesses of the pachytene $\mathrm{X}$ and $\mathrm{Y}$ chromosomes can be explained by the specific accumulation of structural proteins in the SC.

General patterns were manifested in the distribution of recombination nodules in the XY bivalent in the 52-chromosome mole rats. The region with the predominant MLH1 position is located in the peritelomeric site, and there are no such MLH1 foci near the centromere. This pattern has been described in many animals [67-69] and in humans [61]. It is worth noting that MLH1 signals in the XY bivalent were identified in $16.9 \%$ of the nuclei. The indicator is quite variable in different mammals and can be distinct for several reasons. As we noted earlier [20], the reason for this may be a short period of time when the chromosomes recombine, or a powerful protein cover around the sex chromosomes causing chromatin inactivation that could prevent the penetration of anti-MLH1 antibodies.

Why was an MLH1 focus not identified in the sex bivalent of the 60-chromosome form? We assume that this was due to intercentromere interference. It has long been known that the crossing-over is limited near the centromere [70-72]. Along with that, atypical recombination within the near-centromere regions can lead to loss of chromosomes [73]. The suppression of recombination might be due to the presence of pericentromeric heterochromatin $[69,74]$. As the mole rat $X$ and $Y$ chromosomes have large blocks of $C$-heterochromatin localized at different ends of the short synaptic segment, this may limit or prohibit the formation of recombination nodules. The evolutionary role of the suppression of recombination, including chromosomal speciation, has been widely discussed [75-78] and could have occurred in the evolution of mole rats. We cannot exclude that the evolutionary centromere displacement in the $\mathrm{Y}$ chromosome could reformat the homologous site of the sex chromosomes. This could lead to a shortening of the segment of true homology, up to the point where the short homologous region can be interstitial, and, as a consequence, to the absence of the MLH1 signal.

\subsection{Differences in Nannospalax ehrenbergi Sex Chromosomes}

The application of the FISH method allowed us to demonstrate different patterns of telomere sequences distribution in the $\mathrm{Y}$ chromosomes of Israeli mole rats (Figure 1c,d). Previously, it has been shown that the $Y$ chromosome of the $2 n=52$ form differs from the $Y$ of the $2 n=60$ form with regard to a bright interstitial $\mathrm{CMA}_{3}$ (chromomycin $\mathrm{A}_{3}$ ) band. A thin interstitial hybridization band of species-specific DNA in the $Y$ chromosome of the $2 n=52$ form was detected by comparative genomic in situ hybridization [58].

Such differences are confirmed by this study. Here, we have established that the sex chromosomes of the two mole rat forms present different synaptic and recombination patterns. Thus, Israeli N. ehrenbergi are marked by two types of the $\mathrm{Y}$ chromosome. Our data shed light on the possible ways in which the $Y$ chromosome diverges within this group.

\subsection{Trends and Possible Ways of Y Chromosome Evolution in Nannospalax ehrenbergi}

On the basis of the differences in the location of the centromeres in the male chromosome, we suggest possible scenarios for the reorganization of the $Y$ chromosome. One way is to change the position of the centromere of the $Y$ chromosome through pericentric inversion (Figure 6a). This type 
of rearrangement takes place in the evolution of the male sex chromosome in some mammals [79]. On the one hand, a large block of C-heterochromatin in the $\mathrm{Y}$ chromosome of the 60-chromosome form can indicate this event. Probably, restructuring of the PAR may be supported by synaptic differences in the telomeric regions (Figure 3j). On the other hand, it should cause changes in the G-pattern. However, as was noted above, the $\mathrm{Y}$ chromosome of the two chromosomal forms presented almost the same G-pattern [58].

A second variant of chromosome alteration might be as follows. A new centromere in a $\mathrm{Y}$ chromosome of the 60-chromosome form could emerge de novo with subsequent inactivation of the old centromere (Figure $6 \mathrm{~b}$ ). As a rule, the new centromere will not form a C-heterochromatin or it will be very small [80], as, for example, in the non-Robertsonian pair of submetacentrics in the Ellobius tancrei $[21,81]$. C-heterochromatin near the old centromere could be eroded. However, the existence of large C-heterochromatin blocks in the $\mathrm{Y}$ chromosome conflicts with this scenario.

Perhaps, the most likely scenario is the reorganization of the ancestral $Y$ chromosome through centromeric transposition (Figure 6c). In this case, the centromere moves from one end of the $\mathrm{Y}$ chromosome to the other. It is probable that a minimal change in the G-pattern could occur. The centromere could change its position together with C-heterochromatin. We believe that centromeric transposition is a possible mechanism, because the similar data were reported for other species $[82,83]$.

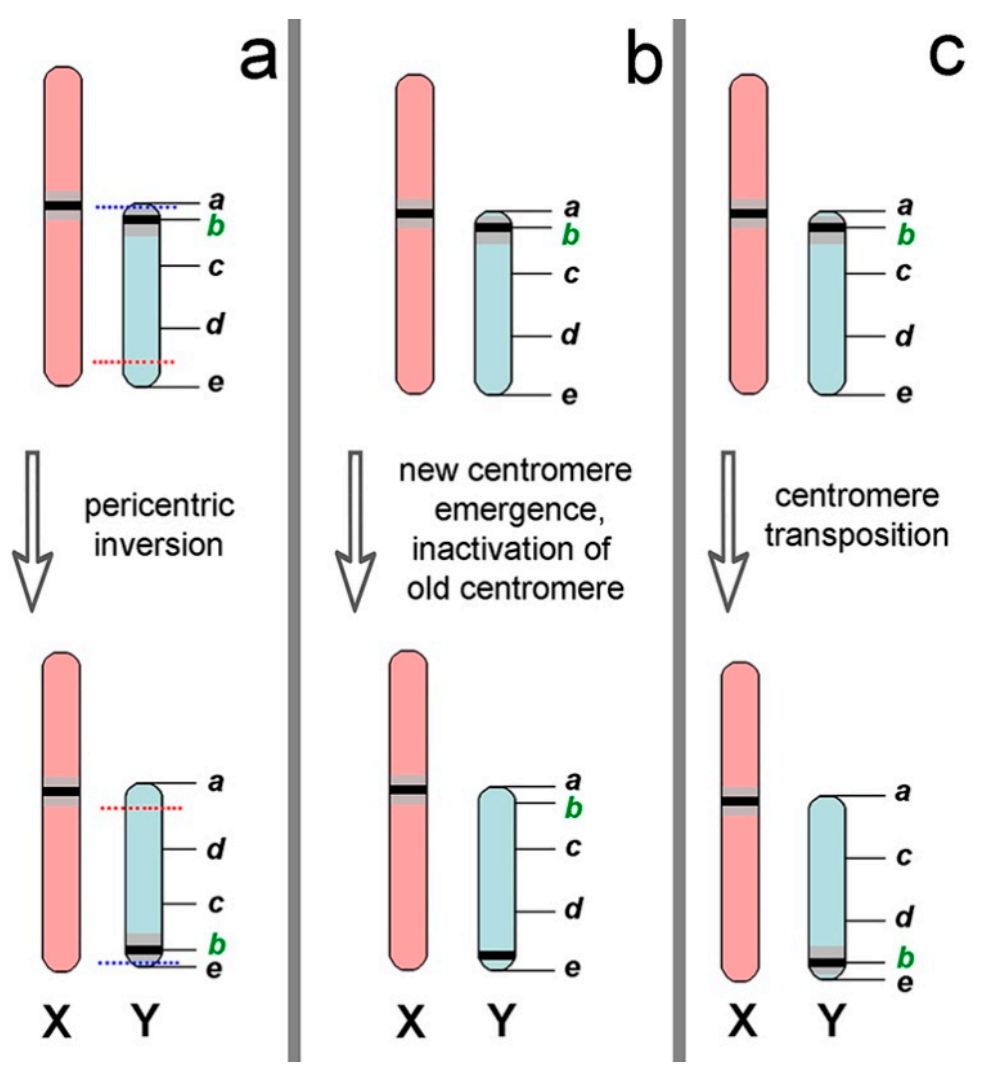

Figure 6. Possible scenarios of the $\mathrm{Y}$ chromosome reorganization in the 60-chromosome N. ehrenbergi. (a) Pericentric inversion changes the position of the centromere in the $\mathrm{Y}$ chromosome. The blue and red lines correspond to the points of chromosome breaks; (b) formation of de novo centromeres with simultaneous or subsequent inactivation of the old centromere and erosion of C-heterochromatin; (c) the centromere, together with heterochromatin, moves to a new position (centromere transposition). The green letter $b$ marks the position of the ancestral centromere.

The consequences of the centromeric relocation in the $\mathrm{Y}$ chromosome appear to be different in the synaptic and recombination patterns of the sex chromosomes in closely related mole rats. 
Thus, 60-chromosome mole rats probably demonstrate a unique case of synaptic but achiasmate sex chromosomes. This phenomenon requires further study. To clarify the most probable pathway of the evolution of the $\mathrm{Y}$ chromosome, it is important to perform FISH mapping of male sex chromosomes in different mole rat forms, similar to the work of Di Meo et al. [79].

Most likely, the reorganization of the Y chromosome within N. ehrenbergi arose after the Spalax and Nannospalax divergence and independent of autosomal rearrangements (Robertsonian translocations, paracentric inversions, and centromeric shifts). Since the $Y$ chromosomes of all Israeli N. ehrenbergi, and even of two of the 60-chromosome forms of N. xanthodon from the north of Turkey (Spalax leucodon sensu lato), are of the same size and present very similar G- and C-banding patterns, it is probable that the reorganization of the $\mathrm{Y}$ chromosome in the Israeli 60-chromosome forms is a relatively recent evolutionary event.

The change in the position of the centromere of the $Y$ chromosome could affect the structure of the PAR. This is confirmed by the fact that we identified a short-term disturbance in the synaptic co-orientation of the $\mathrm{X}$ and $\mathrm{Y}$ telomeric regions (Figure 3j), as in Mus musculus. Two mouse subspecies, Mus musculus domesticus and Mus musculus castaneus, differ in terms of the shift in the PAR boundary [84]. Restructuring led to a decrease in the recombination level and to the death of meiotic cells in mouse intersubspecific hybrids [85].

It is known that a lack of recombination in autosomes and sex chromosomes can lead to incorrect segregation of chromosomes, formation of unbalanced gametes, and in general a decrease in fertility or even sterility [86]. Aneuploid spermatozoa were previously detected in M. m. domesticus $\times$ M. $m$. castaneus hybrids, although they retained fertility [85]. It can be assumed that the lack of recombination of the $\mathrm{X}$ and $\mathrm{Y}$ chromosomes in the 60-chromosome mole rats may have consequences for their successful segregation and increase the number of errors in the formation of mature spermatozoa. However, it is worth noting that recombination, or even synapsis of the sex chromosomes, is lacking in some mammalian species. These species do not have PAR, and their sex chromosomes are always asynaptic, but this does not affect meiotic progression [87]. This phenomenon demonstrates diversity in sex chromosomes evolution.

We hypothesize that only after the autosomal divergence of the mole rat forms, the $\mathrm{Y}$ chromosome in the nearest ancestor of the $2 n=52$ and $2 n=54$ chromosomal forms was subject to insertions or amplification of telomeric sequences [58]. Similar chromosomal reconstructions have been proposed in the evolution of sex chromosomes [88]. The assumption that independent events of duplication or amplification lead to the fixation of different variants of satellite DNA in the autosomes of Israeli mole rat forms [58] confirms our hypothesis. It should be noted that the telomeric pattern has been used as a marker to analyze the inheritance of sex chromosomes in heterozygous mole rats in a hybrid zone [59].

Existing findings, combined with the data presented here and our unpublished data from the Miilya hybrid zone [89], allow us to conclude that the structural and functional patterns of the $\mathrm{Y}$ chromosome in the 52- and 54-chromosome mole rats are identical, just as the $\mathrm{Y}$ chromosomes in the 58 - and 60-chromosome forms do not differ. We assume that the two groups ("52-54" and "58-60") were each formed from separate ancestral lines (Figure 7). Possibly, the lines became independent around 280,000 years ago, in accordance with the analysis of allozyme diversity [90] or in the time interval 1.2-2.4 Mya, calculated on the basis of the mean rate of divergence for mammalian mitochondrial DNA [91]. Nevo et al. [92] explained the time differences by the molecular clock or the heterogeneity of the rate of DNA evolution.

What might be the evolutionary fate of the reconstructed $Y$ chromosome in the 60-chromosome form? Perhaps, recombination, the shuffling of genes, reduces the mutation burden. However, the absence of recombination will favor the accumulation of deleterious mutant genes through the Muller ratchet [93], and the $Y$ chromosome will be subject to attrition [23] and degradation [94]. If such a history awaits the male sex chromosome, then undoubtedly it could be a driver of further enhancement of the divergence in mole rats. 
A wide autosomal variability might frequently be synchronized or connected with sex chromosome reorganization or even with the emergence of nonclassical systems of sex chromosomes. For example, mice Mus possess an incredible variability of autosomes and diverse types of sex chromosomes changes, such as displacement of the PAR border [84], heterochromatin variations [95], Robertsonian translocations [96,97], whole-arm reciprocal translocation (WART) [98], and sex-reverse mutation ( $X Y$ female) [5]. Considerable chromosomal variations and sex trivalent $X Y_{1} Y_{2}$ have been described in males with different karyotypes of the common shrew Sorex araneus [99,100]. The eastern mole vole has been shown to present unique XX chromosomes in males and females and extreme autosomal variability [4]. Blind mole rats can probably be counted in this group as the reorganization of their $\mathrm{Y}$ chromosomes is apparently interconnected with their autosomal changes. Undoubtedly, autosome and sex chromosome variabilities might have a cumulative effect and reinforce the divergence of chromosomal races. Indeed, sex chromosomes rearrangements in heterozygous animals can limit or prohibit the progression of gametogenesis, form aneuploid gametes, and lead to a decrease in fertility [86,101-103].

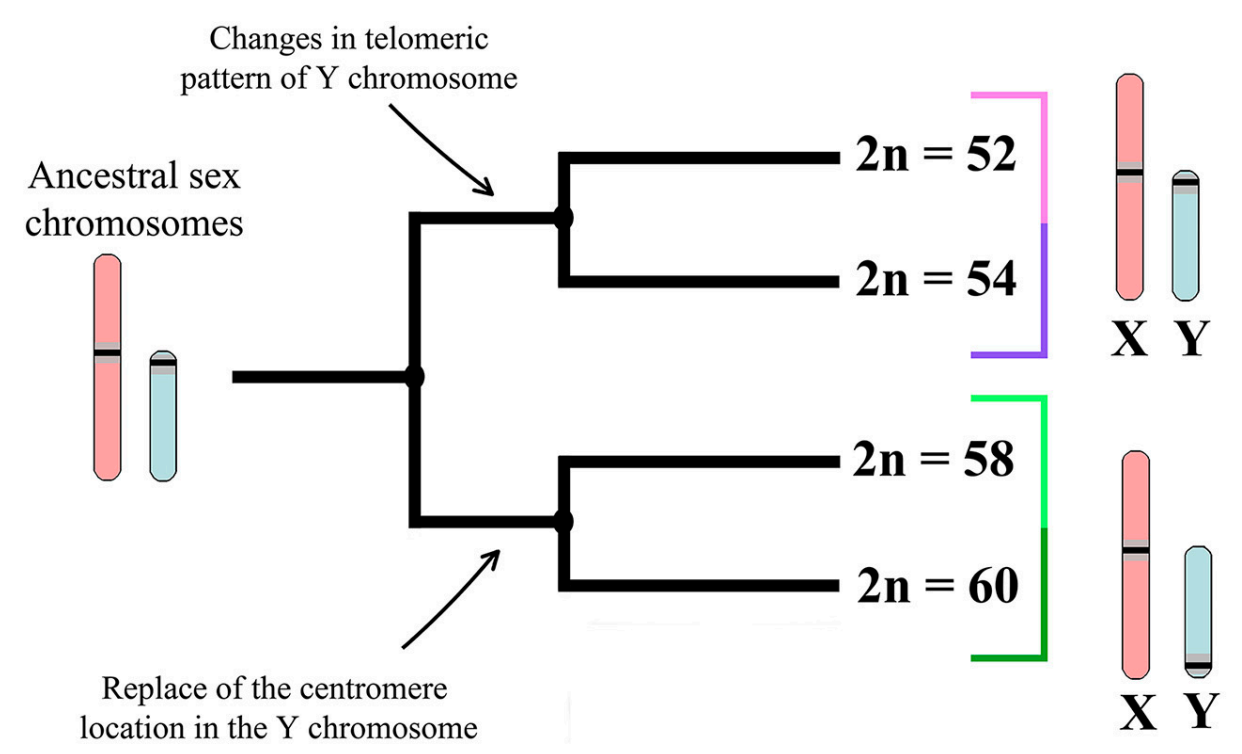

Figure 7. Scheme of sex chromosome differences in Israeli N. ehrenbergi based on cytogenetic data.

\section{Conclusions}

The results presented here underline the diversity between different karyotypes found in $N$. erhenbergi. We assume that it is most appropriate to divide all Israeli mole rats into two large clusters: ' $2 \mathrm{n}=52-2 \mathrm{n}=54^{\prime}$ and ' $2 \mathrm{n}=58-2 \mathrm{n}=6$ ' $^{\prime}$ (Figure 7). The division into two clusters is supported by the analysis of mitochondrial DNA [91,92,104,105]. Most likely, each cluster corresponds to the species status, and the representatives within each cluster correspond to the level of the chromosomal form. The species status is given for each chromosomal form of Israeli mole rats on the basis of extensive studies (summarized in [48]). However, according to the biological species concept, reproductive isolation is a key issue. Its detailed analysis permits the most adequate discussion of diversification within the different taxa. Wahrman et al. [42] started this field of study, but it should be continued. Studies of meiosis in different forms and their hybrids will help to decipher the mechanisms of reproductive isolation. To identify signs of meiotic arrest and sterility, it is necessary to study the features of meiotic progression and gametogenesis in 'inter-cluster' and 'intra-cluster' mole rat hybrids.

To date, meiotic studies of the structure and behavior of the sex chromosomes have confirmed the deep diversification in the N. ehrenbergi superspecies complex and the prospect for evolutionary studies in the mammalian group. 
Author Contributions: S.M., E.I., V.S., I.B., O.K. conceived and designed the experiments. S.M., E.I., V.S. participated in the expeditions and prepared the cytological preparations. S.M. performed immunostaining and fluorescent and electron microscopy. E.I. performed G- and C-staining and FISH. All authors analyzed the data and wrote the main manuscript.

Acknowledgments: This work was partially supported by the research grants of the Program of the Russian Academy of Sciences' Presidium No. 41 'Biodiversity of Natural Systems and Biological Resources of Russia', the Russian Foundation for Basic Research Nos. 15-29-02649, 16-04-01447, VIGG RAS State Assignment Contract No. 0112-2016-0008 and IDB RAS Government basic research program No. 0108-2018-0007. We thank the Genetic Polymorphisms Core Facility of the Vavilov Institute of General Genetics of the Russian Academy of Sciences, Moscow for the possibility to use their microscopes. We thank Imad Shams for training in catching the mole rats and working with them, Matěj Lövy for the possibility to use catch equipment. We are grateful to G.N. Davidovich and A.G. Bogdanov of the Electron Microscopy Laboratory of the Biological Faculty of Moscow State University, Moscow, Russia for the technical assistance and to the reviewers for their helpful comments.

Conflicts of Interest: The authors declare no conflict of interest.

\section{References}

1. Ezaz, T.; Srikulnath, K.; Graves, J.A.M. Origin of amniote sex chromosomes: An ancestral super-sex chromosome, or common requirements? J. Hered. 2016, 108, 94-105. [CrossRef] [PubMed]

2. Graves, J.A.M. Weird animal genomes and the evolution of vertebrate sex and sex chromosomes. Annu. Rev. Genet. 2008, 42, 565-586. [CrossRef] [PubMed]

3. Fredga, K. Unusual sex chromosome inheritance in mammals. Philos. Trans. R. Soc. Lond. B 1970, $259,15-36$. [CrossRef]

4. Vorontsov, N.N.; Lyapunova, E.A.; Borissov, Y.M.; Dovgal, V.E. Variability of sex chromosomes in mammals. Genetica 1980, 52/53, 361-372. [CrossRef]

5. Veyrunes, F.; Chevret, P.; Catalan, J.; Castiglia, R.; Watson, J.; Dobigny, G.; Robinson, T.J.; Britton-Davidian, J. A novel sex determination system in a close relative of the house mouse. Proc. R. Soc. Lond. B Biol. Sci. 2010, 277, 1049-1056. [CrossRef] [PubMed]

6. Fredga, K. Aberrant chromosomal sex-determining mechanisms in mammals, with special reference to species with XY females. Philos. Trans. R. Soc. Lond. B 1988, 322, 83-95. [CrossRef]

7. Yoshida, K.; Kitano, J. The contribution of female meiotic drive to the evolution of neo-sex chromosomes. Evolution 2012, 66, 3198-3208. [CrossRef] [PubMed]

8. Cortez, D.; Marin, R.; Toledo-Flores, D.; Froidevaux, L.; Liechti, A.; Waters, P.D.; Grützner, F.; Kaessmann, H. Origins and functional evolution of Y chromosomes across mammals. Nature 2014, 508, 488-493. [CrossRef] [PubMed]

9. Graves, J.A.M. Sex chromosome specialization and degeneration in mammals. Cell 2006, 124, 901-914. [CrossRef] [PubMed]

10. Hsu, T.C.; Arrighi, F.E. Distribution of constitutive heterochromatin in mammalian chromosomes. Chromosoma 1971, 34, 243-253. [CrossRef] [PubMed]

11. Muller, H.J. A gene for the fourth chromosome of Drosophila. J. Exp. Zool 1914, 17, 325-336. [CrossRef]

12. Fisher, R.A. The evolution of dominance. Biol. Rev. 1931, 6, 345-368. [CrossRef]

13. Nei, M. Linkage modification and sex difference in recombination. Genetics 1969, 63, 681-699. [PubMed]

14. Bull, J.J. Evolution of Sex Determining Mechanisms; The Benjamin-Cummings Publishing Company: San Francisco, CA, USA, 1983; p. 316.

15. Peneder, P.; Wallner, B.; Vogl, C. Exchange of genetic information between therian X and Y chromosome gametologs in old evolutionary strata. Ecol. Evol. 2017, 7, 8478-8487. [CrossRef] [PubMed]

16. Ohno, S. Sex Chromosomes and Sex-Linked Genes; Springer: Berlin/Heidelberg, Germany; New York, NY, USA, 1967; p. 191.

17. Charlesworth, B.; Charlesworth, D. The degeneration of Y chromosomes. Philos. Trans. R. Soc. Lond. B Biol. Sci. 2000, 355, 1563-1572. [CrossRef] [PubMed]

18. Bachtrog, D. Y-chromosome evolution: Emerging insights into processes of Y-chromosome degeneration. Nat. Rev. Genet. 2013, 14, 113-124. [CrossRef] [PubMed]

19. Kolomiets, O.L.; Vorontsov, N.N.; Lyapunova, E.A.; Mazurova, T.F. Ultrastructure, meiotic behavior, and evolution of sex chromosomes of the genus Ellobius. Genetica 1991, 84, 179-189. [CrossRef] 
20. Matveevsky, S.; Bakloushinskaya, I.; Kolomiets, O. Unique sex chromosome systems in Ellobius: How do male XX chromosomes recombine and undergo pachytene chromatin inactivation? Sci. Rep. 2016, 6, 29949. [CrossRef] [PubMed]

21. Matveevsky, S.; Kolomiets, O.; Bogdanov, A.; Hakhverdyan, M.; Bakloushinskaya, I. Chromosomal evolution in mole voles Ellobius (Cricetidae, Rodentia): Bizarre sex chromosomes, variable autosomes and meiosis. Genes 2017, 8, 306. [CrossRef] [PubMed]

22. Arakawa, Y.; Nishida-Umehara, C.; Matsuda, Y.; Sutou, S.; Suzuki, H. X-chromosomal localization of mammalian Y-linked genes in two XO species of the Ryukyu spiny rat. Cytogenet. Genome Res. 2002, 99, 303-309. [CrossRef] [PubMed]

23. Graves, J.A.M. The origin and function of the mammalian $Y$ chromosome and Y-borne genes-An evolving understanding. Bioessays 1995, 17, 311-320. [CrossRef] [PubMed]

24. Saxena, R.; Brown, L.G.; Hawkins, T.; Alagappan, R.K.; Skaletsky, H.; Reeve, M.P.; Reijo, R.; Rozen, S.; Dinulos, M.B.; Disteche, C.M.; et al. The DAZ gene cluster on the human Y chromosome arose from an autosomal gene that was transposed, repeatedly amplified and pruned. Nat. Genet. 1996, 14, $292-299$. [CrossRef] [PubMed]

25. Skaletsky, H.; Kuroda-Kawaguchi, T.; Minx, P.J.; Cordum, H.S.; Hillier, L.; Brown, L.G.; Repping, S.; Pyntikova, T.; Ali, J.; Bieri, T.; et al. The male-specific region of the human Y chromosome is a mosaic of discrete sequence classes. Nature 2003, 423, 825-837. [CrossRef] [PubMed]

26. Griffin, D.K. Is the $\mathrm{Y}$ chromosome disappearing?-Both sides of the argument. Chromosome Res. 2012, 20, 35-45. [CrossRef] [PubMed]

27. Murata, C.; Kuroki, Y.; Imoto, I.; Kuroiwa, A. Ancestral Y-linked genes were maintained by translocation to the $\mathrm{X}$ and $\mathrm{Y}$ chromosomes fused to an autosomal pair in the Okinawa spiny rat Tokudaia muenninki. Chromosome Res. 2016, 24, 407-419. [CrossRef] [PubMed]

28. Fredga, K. A new sex determining mechanism in a mammal. Chromosomes of Indian mongoose (Herpestes auropunctatus). Hereditas 1965, 52, 411-420. [CrossRef] [PubMed]

29. Murata, C.; Sawaya, H.; Nakata, K.; Yamada, F.; Imoto, I.; Kuroiwa, A. The cryptic Y-autosome translocation in the small Indian mongoose, Herpestes auropunctatus, revealed by molecular cytogenetic approaches. Chromosoma 2016, 125, 807-815. [CrossRef] [PubMed]

30. Ma, N.S.F.; Elliott, M.W.; Morgan, L.; Miller, A.; Jones, T.C. Translocation of Y chromosome to an autosome in the Bolivian owl monkey. Aotus. Am. J. Phys. Anthrop. 1976, 45, 191-201. [CrossRef] [PubMed]

31. Pieczarka, J.C.; de Souza Barros, R.M.; De Faria, F.M.; Nagamachi, C.Y. Aotus from the southwestern Amazon region is geographically and chromosomally intermediate between A. azarae boliviensis and A. infulatus. Primates 1993, 34, 197-204. [CrossRef]

32. Stanyon, R.; Garofalo, F.; Steinberg, E.R.; Capozzi, O.; Di Marco, S.; Nieves, M.; Archidiacono, N.; Mudry, M.D. Chromosome painting in two genera of South American monkeys: Species identification, conservation, and management. Cytogenet. Genome Res. 2011, 134, 40-50. [CrossRef] [PubMed]

33. Steinberg, E.R.; Nieves, M.; Mudry, M.D. Multiple sex chromosome systems in howler monkeys (Platyrrhini, Alouatta). Comp. Cytogenet. 2014, 8, 43-69. [CrossRef] [PubMed]

34. Schempp, W.; Toder, R. Evolution of the mammalian XY pairing segment. Chromosomes Today 1993, 11, $277-283$.

35. Burgoyne, P.S. Genetic homology and crossing over in the $X$ and $Y$ chromosomes of mammals. Hum. Genet. 1982, 61, 85-90. [CrossRef] [PubMed]

36. Lahn, B.T.; Page, D.C. Four evolutionary strata on the human X chromosome. Science 1999, $286,964-967$. [CrossRef] [PubMed]

37. Bernstein, R.; Wadee, A.; Rosendorff, J.; Wessels, A.; Jenkins, T. Inverted Y chromosome polymorphism in the Gujerati Muslim Indian population of South Africa. Hum. Genet. 1986, 74, 223-229. [CrossRef] [PubMed]

38. Hsu, L.Y.; Benn, P.A.; Tannenbaum, H.L.; Perlis, T.E.; Carlson, A.D.; Opitz, J.M.; Reynolds, J.F. Chromosomal polymorphisms of 1,9,16, and $\mathrm{Y}$ in 4 major ethnic groups: A large prenatal study. Am. J. Med. Genet. Part A 1987, 26, 95-101. [CrossRef] [PubMed]

39. Tomomasa, H.; Adachi, Y.; Iwabuchi, M.; Oshio, S.; Umeda, T.; Iino, Y.; Takano, T.; Nakahori, Y. Pericentric inversion of the Y chromosome of infertile male. Arch. Androl. 2000, 45, 181-185. [CrossRef] [PubMed] 
40. Tyler-Smith, C.; Gimelli, G.; Giglio, S.; Floridia, G.; Pandya, A.; Terzoli, G.; Warburton, P.E.; Earnshaw, W.C.; Zuffardi, O. Transmission of a fully functional human neocentromere through three generations. Am. J. Hum. Genet. 1999, 64, 1440-1444. [CrossRef] [PubMed]

41. Wahrman, J.; Goitein, R.; Nevo, E. Mole rat Spalax: Evolutionary significance of chromosome variation. Science 1969, 164, 82-84. [CrossRef] [PubMed]

42. Wahrman, J.; Richler, C.; Gamperl, R.; Nevo, E. Revisiting Spalax: Mitotic and meiotic chromosome variability. Isr. J. Zool. 1985, 33, 15-38. [CrossRef]

43. Shams, I.; Avivi, A.; Nevo, E. Hypoxic stress tolerance of the blind subterranean mole rat: Expression of erythropoietin and hypoxia-inducible factor $1 \alpha$. Proc. Natl. Acad. Sci. USA 2004, 101, 9698-9703. [CrossRef] [PubMed]

44. Brodsky, L.I.; Jacob-Hirsch, J.; Avivi, A.; Trakhtenbrot, L.; Zeligson, S.; Amariglio, N.; Paz, A.; Korol, B.; Band, M.; Rechavi, G.; et al. Evolutionary regulation of the blind subterranean mole rat, Spalax, revealed by genome-wide gene expression. Proc. Natl. Acad. Sci. USA 2005, 102, 17047-17052. [CrossRef] [PubMed]

45. Gorbunova, V.; Seluanov, A.; Zhang, Z.; Gladyshev, V.N.; Vijg, J. Comparative genetics of longevity and cancer: Insights from long-lived rodents. Nat. Rev. Genet. 2014, 15, 531-540. [CrossRef] [PubMed]

46. Schmidt, H.; Malik, A.; Bicker, A.; Poetzsch, G.; Avivi, A.; Shams, I.; Hankeln, T. Hypoxia tolerance, longevity and cancer-resistance in the mole rat Spalax-A liver transcriptomics approach. Sci. Rep. 2017, 7, 14348. [CrossRef] [PubMed]

47. Arslan, A.; Kryštufek, B.; Matur, F.; Zima, J. Review of chromosome races in blind mole rats (Spalax and Nannospalax). Folia Zool. 2016, 65, 249-301. [CrossRef]

48. Nevo, E.; Ivanitskaya, E.; Beiles, A. Adaptive Radiation of Blind Subterranean Mole Rats: Naming and Revisiting the Four Sibling Species of the Spalax ehrenbergi Superspecies in Israel: Spalax galili $(2 n=52)$, S. golani $(2 n=54)$, S. carmeli $(2 n=58)$ and S. judaei $(2 n=60)$; Backhuys Publishers: Leiden, The Netherlands, 2001; p. 190.

49. Qumsiyeh, M.B. Mammals of the Holy Land; Texas Tech University Press: Lubbock, TX, USA, 1996; p. 389.

50. Ivanitskaya, E.; Coskun, Y.; Nevo, E. Banded karyotypes of mole rats (Spalax, Spalacidae, Rodentia) from Turkey: A comparative analysis. J. Zool. Syst. Evol. Res. 1997, 35, 171-177. [CrossRef]

51. Ivanitskaya, E.; Nevo, E. Cytogenetics of mole rats of the Spalax ehrenbergi superscpecies from Jordan (Spalacidae, Rodentia). Zeitschrift fur Saugetierkunde 1998, 63, 336-346.

52. Stokes, W.S. Reducing unrelieved pain and distress in laboratory animals using humane endpoints. ILAR J. 2000, 41, 59-60. [CrossRef]

53. Lee, M.R.; Elder, F.F.B. Yeast stimulation of bone marrow mitosis for cytogenetic investigations. Cytogenet. Genome Res. 1980, 26, 36-40. [CrossRef] [PubMed]

54. Sumner, A.T. A simple technique for demonstrating centromeric heterochromatin. Exp. Cell Res. 1972, 75, 304-306. [CrossRef]

55. Seabright, M. A rapid banding technique for human chromosomes. Lancet 1971, 11, 971-972. [CrossRef]

56. Navarro, J.; Vidal, F.; Guitart, M.; Egozcue, J. A method for the sequential study of synaptonemal complexes by light and electron microscopy. Hum. Genet. 1981, 59, 419-421. [CrossRef] [PubMed]

57. Kolomiets, O.L.; Matveevsky, S.N.; Bakloushinskaya, I.Y. Sexual dimorphism in prophase I of meiosis in the Northern mole vole (Ellobius talpinus Pallas, 1770) with isomorphic (XX) chromosomes in males and females. Comp. Cytogenet. 2010, 4, 55-66. [CrossRef]

58. Ivanitskaya, E.; Belyayev, A.; Nevo, E. Heterochromatin differentiation shows the pathways of karyotypic evolution in Israeli mole rats (Spalax, Spalacidae, Rodentia). Cytogenet. Genome Res. 2005, 111, 159-165. [CrossRef] [PubMed]

59. Ivanitskaya, E.; Rashkovetsky, L.; Nevo, E. Chromosomes in a hybrid zone of Israeli mole rats (Spalax, Radentia). Russ. J. Genet. 2010, 46, 1149-1151. [CrossRef]

60. Solari, A.J.; Rahn, M.I. Asymmetry and resolution of the synaptonemal complex in the XY pair of Chinchilla laniger. Genetica 1985, 67, 63-71. [CrossRef]

61. Anderson, L.K.; Reeves, A.; Webb, L.M.; Ashley, T. Distribution of crossing over on mouse synaptonemal complexes using immunofluorescent localization of MLH1 protein. Genetics 1999, 151, 1569-1579. [PubMed]

62. Dresser, M.E.; Moses, M.J. Synaptonemal complex karyotyping in spermatocytes of the Chinese hamster (Cricetulus griseus). IV. Light and electron microscopy of synapsis and nucleolar development by silver staining. Chromosoma 1980, 76, 1-22. [CrossRef] [PubMed] 
63. Solari, A.J.; Pigozzi, M.I. Fine structure of the $\mathrm{XY}$ body in the $\mathrm{XY}_{1} \mathrm{Y}_{2}$ trivalent of the bat Artibeus lituratus. Chromosome Res. 1994, 2, 53-58. [CrossRef] [PubMed]

64. Bonvicino, C.R.; D'Andrea, P.S.; Borodin, P.M. Pericentric inversion in natural populations of Oligoryzomys nigripes (Rodentia: Sigmodontinae). Genome 2001, 44, 791-796. [CrossRef] [PubMed]

65. Sciurano, R.B.; Merani, M.S.; Bustos, J.; Solari, A.J. Synaptonemal complexes and XY behavior in two species of Argentinian armadillos: Chaetophractus villosus and Dasypus hybridus (Xenarthra, Dasypodidae). Biocell 2006, 30, 57-66. [PubMed]

66. Joseph, A.M.; Chandley, A.C. The morphological sequence of XY pairing in the Norway rat Rattus norvegicus. Chromosoma 1984, 89, 381-386. [CrossRef] [PubMed]

67. Yang, Q.; Zhang, D.; Leng, M.; Yang, L.; Zhong, L.; Cooke, H.J.; Shi, Q. Synapsis and meiotic recombination in male Chinese muntjac (Muntiacus reevesi). PLoS ONE 2011, 6, e19255. [CrossRef] [PubMed]

68. Waters, P.D.; Ruiz-Herrera, A.; Dobigny, G.; Caldès, M.G.; Robinson, T.J. Sex chromosomes of basal placental mammals. Chromosoma 2007, 116, 511-518. [CrossRef] [PubMed]

69. Segura, J.; Ferretti, L.; Ramos-Onsins, S.; Capilla, L.; Farré, M.; Reis, F.; Oliver-Bonet, M.; Fernández-Bellón, H.; Garcia, F.; Garcia-Caldés, M.; et al. Evolution of recombination in eutherian mammals: Insights into mechanisms that affect recombination rates and crossover interference. Proc. R. Soc. Lond. B Biol. Sci. 2013, 280, 20131945. [CrossRef] [PubMed]

70. Lindsley, D.L.; Sandler, L. The genetic analysis of meiosis in female Drosophila melanogaster. Philos. Trans. R. Soc. Lond. B 1977, 277, 295-312. [CrossRef]

71. Charlesworth, B.; Langley, C.H.; Stephan, W. The evolution of restricted recombination and the accumulation of repeated DNA sequences. Genetics 1986, 112, 947-962. [PubMed]

72. Davisson, M.T.; Akeson, E.C. Recombination suppression by heterozygous Robertsonian chromosomes in the mouse. Genetics 1993, 133, 649-667. [PubMed]

73. Topp, C.N.; Dawe, R.K. Reinterpreting pericentromeric heterochromatin. Curr. Opin. Plant Biol. 2006, 9, 647-653. [CrossRef] [PubMed]

74. Froenicke, L.; Anderson, L.K.; Wienberg, J.; Ashley, T. Male mouse recombination maps for each autosome identified by chromosome painting. Am. J. Hum. Genet. 2002, 71, 1353-1368. [CrossRef] [PubMed]

75. Rice, W.R. Evolution of the Y sex chromosome in animals. Bioscience 1996, 46, 331-343. [CrossRef]

76. Bergero, R.; Charlesworth, D. The evolution of restricted recombination in sex chromosomes. Trends Ecol. Evol. 2009, 24, 94-102. [CrossRef] [PubMed]

77. Jackson, B.C. Recombination-suppression: How many mechanisms for chromosomal speciation? Genetica 2011, 139, 393-402. [CrossRef] [PubMed]

78. Matsumoto, T.; Yoshida, K.; Kitano, J. Contribution of gene flow to the evolution of recombination suppression in sex chromosomes. J. Theor. Biol. 2017, 431, 25-31. [CrossRef] [PubMed]

79. Di Meo, G.P.; Perucatti, A.; Floriot, S.; Incarnato, D.; Rullo, R.; Jambrenghi, A.C.; Ferretti, L.; Vonghia, G.; Cribiu, E.; Eggen, A.; et al. Chromosome evolution and improved cytogenetic maps of the $Y$ chromosome in cattle, zebu, river buffalo, sheep and goat. Chromosome Res. 2005, 13, 349-355. [CrossRef] [PubMed]

80. Warburton, P.E. Chromosomal dynamics of human neocentromere formation. Chromosome Res. 2004, $12,617$. [CrossRef] [PubMed]

81. Bakloushinskaya, I.Y.; Matveevsky, S.N.; Romanenko, S.A.; Serdukova, N.A.; Kolomiets, O.L.; Spangenberg, V.E.; Lyapunova, E.A.; Graphodatsky, A.S. A comparative analysis of the mole vole sibling species Ellobius tancrei and E. talpinus (Cricetidae, Rodentia) through chromosome painting and examination of synaptonemal complex structures in hybrids. Cytogenet. Genome Res. 2012, 136, 199-207. [CrossRef] [PubMed]

82. Nergadze, S.G.; Piras, F.M.; Gamba, R.; Corbo, M.; Cerutti, F.; McCarter, J.G.W.; Cappelletti, E.; Gozzo, F.; Harman, R.M.; Antczak, D.F.; et al. Birth, evolution, and transmission of satellite-free mammalian centromeric domains. Genome Res. 2018. [CrossRef] [PubMed]

83. Schubert, I. What is behind "centromere repositioning"? Chromosoma 2018, 127, 229-234. [CrossRef] [PubMed]

84. White, M.A.; Ikeda, A.; Payseur, B.A. A pronounced evolutionary shift of the pseudoautosomal region boundary in house mice. Mamm. Genome 2012, 23, 454-466. [CrossRef] [PubMed]

85. Dumont, B.L. Meiotic consequences of genetic divergence across the murine pseudoautosomal region. Genetics 2017, 205, 1089-1100. [CrossRef] [PubMed] 
86. King, M. Species Evolution: The Role of Chromosome Change; Cambridge University Press: Cambridge, UK, 1993; p. 366.

87. De la Fuente, R.; Sánchez, A.; Marchal, J.A.; Viera, A.; Parra, M.T.; Rufas, J.S.; Page, J. A synaptonemal complex-derived mechanism for meiotic segregation precedes the evolutionary loss of homology between sex chromosomes in arvicolid mammals. Chromosoma 2012, 121, 433-446. [CrossRef] [PubMed]

88. Charlesworth, B. The evolution of sex chromosomes. Science 1991, 251, 1030-1033. [CrossRef] [PubMed]

89. Matveevsky, S.N. Vavilov Institute of General Genetics, Russian Academy of Sciences, Moscow, Russia. Materials and data about mole rats in Miilya hybrid zone, Israel. 2016.

90. Nevo, E.; Filippucci, M.G.; Beiles, A. Genetic polymorphisms in subterranean mammals (Spalax ehrenbergi superspecies) in the near East revisited: Patterns and theory. Heredity 1994, 72, 465-487. [CrossRef] [PubMed]

91. Nevo, E.; Honeycutt, R.L.; Yonekawa, H.; Nelson, K.; Hanzawa, N. Mitochondrial DNA polymorphisms in subterranean mole-rats of the Spalax ehrenbergi superspecies in Israel, and its peripheral isolates. Mol. Biol. Evol. 1993, 10, 590-604. [CrossRef] [PubMed]

92. Nevo, E.; Beiles, A.; Spradling, T. Molecular evolution of cytochrome b of subterranean mole rats, Spalax ehrenbergi superspecies, in Israel. J. Mol. Evol. 1999, 49, 215-226. [CrossRef] [PubMed]

93. Muller, H.J. The relation of recombination to mutational advance. Mutat. Res. Fund. Mol. Mech. Mutagen. 1964, 1, 2-9. [CrossRef]

94. Gordo, I.; Charlesworth, B. The speed of Muller's ratchet with background selection, and the degeneration of Y chromosomes. Genet. Res. 2001, 78, 149-161. [CrossRef] [PubMed]

95. Mitsainas, G.P.; Rovatsos, M.T.; Athanasopoulou, E.B.G. The HSR and heterochromatin distribution in natural populations of Mus musculus domesticus (Rodentia: Murinae) from Greece. Caryologia 2009, 62, 53-61.

96. Jotterand-Bellomo, M. The African Mus genus, an example of karyotypic homogeneity: Cytogenetic study of Mus minutoides/musculoides (Ivory Coast), M. setulosus (Central African Republic), and M. mattheyi (Burkina Faso). Cytogenet. Cell Genet. 1986, 42, 99-104. [CrossRef]

97. Veyrunes, F.; Catalan, J.; Sicard, B.; Robinson, T.J.; Duplantier, J.M.; Granjon, L.; Dobigny, G.; Britton-Davidian, J. Autosome and sex chromosome diversity among the African pygmy mice, subgenus Nannomys (Murinae; Mus). Chromosome Res. 2004, 12, 369-382. [CrossRef] [PubMed]

98. Veyrunes, F.; Watson, J.; Robinson, T.J.; Britton-Davidian, J. Accumulation of rare sex chromosome rearrangements in the African pygmy mouse, Mus (Nannomys) minutoides: A whole-arm reciprocal translocation (WART) involving an X-autosome fusion. Chromosome Res. 2007, 15, 223. [CrossRef] [PubMed]

99. Searle, J.B.; Fedyk, S.; Fredga, K.; Hausser, J.; Volobouev, V.T. Nomenclature for the chromosomes of the common shrew Sorex araneus. Mém. Soc. Vaud. Sci. Nat. 1991, 19, 13-22. [CrossRef]

100. Matveevsky, S.N.; Pavlova, S.V.; Atsaeva, M.M.; Searle, J.B.; Kolomiets, O.L. Dual mechanism of chromatin remodeling in the common shrew sex trivalent $\left(\mathrm{XY}_{1} \mathrm{Y}_{2}\right)$. Comp. Cytogenet. 2017, 11, 727-745. [CrossRef] [PubMed]

101. Guénet, J.L.; Nagamine, C.; Simon-Chazottes, D.; Montagutelli, X.; Bonhomme, F. Hst-3: An X-linked hybrid sterility gene. Genet. Res. 1990, 56, 163-165. [CrossRef] [PubMed]

102. Matsuda, Y.; Hirobe, T.; Chapman, V.M. Genetic basis of XY chromosome dissociation and male sterility in interspecific hybrids. Proc. Natl. Acad. Sci. USA 1991, 88, 4850-4854. [CrossRef] [PubMed]

103. Matsuda, Y.; Moens, P.B.; Chapman, V.M. Deficiency of X and Y chromosomal pairing at meiotic prophase in spermatocytes of sterile interspecific hybrids between laboratory mice (Mus domesticus) and Mus spretus. Chromosoma 1992, 101, 483-492. [CrossRef] [PubMed]

104. Kryštufek, B.; Ivanitskaya, E.; Arslan, A.; Arslan, E.; Buzan, E.V. Evolutionary history of mole rats (genus Nannospalax) inferred from mitochondrial cytochrome b sequence. Biol. J. Linn. Soc. 2012, 105, 446-455. [CrossRef]

105. Hadid, Y.; Németh, A.; Snir, S.; Pavlíček, T.; Csorba, G.; Kázmér, M.; Major, Á.; Mezhzherin, S.; Rusin, M.; Coşkun, Y.; et al. Is evolution of blind mole rats determined by climate oscillations? PLoS ONE 2012, 7, e30043. [CrossRef] [PubMed]

(C) 2018 by the authors. Licensee MDPI, Basel, Switzerland. This article is an open access article distributed under the terms and conditions of the Creative Commons Attribution (CC BY) license (http:/ / creativecommons.org/licenses/by/4.0/). 